\title{
Intersex in the clam Scrobicularia plana (Da Costa): Widespread occurrence in English Channel estuaries and surrounding areas.
}

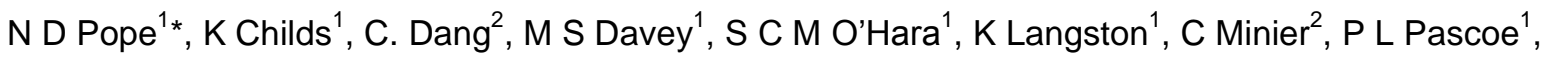
E Shortridge and W J Langston ${ }^{1}$

${ }^{1}$ Marine Biological Association, The Laboratory, Citadel Hill, Plymouth PL1 2PB, UK

2 Laboratory of Ecotoxicology, Universite du Havre, BP540, 76058, Le Havre, France

* Corresponding author. Tel.: +44 1752 633272; fax: +44 1752633102

E-mail address: $\underline{\text { ndpo@mba.ac.uk }}$

Abstract

Estuarine clams Scrobicularia plana were sampled from 108 intertidal locations around the English Channel and adjacent areas. Although S. plana is believed to be a strict gonochorist, $58 \%$ of the populations sampled included intersexed individuals (described as male clams exhibiting ovotestis). Over the entire region, on average, $8.6 \%$ of male clams exhibited intersex, although proportions of affected males ranged from $0 \%$ to $53 \%$ depending on location. The severity of intersex was assessed using a simple classification scale, with the majority of individuals showing low levels of impact. Sex ratios were significantly skewed at some sites. There were no significant relationships between the incidence and severity of intersex; or of associations with size or parasitism of individual clams. Intersex in S. plana is a useful tool to assess endocrine disruptive effects in estuaries, although mechanisms of impact and causative agents remain uncertain.

Keywords:

Intersex, endocrine disruption, Scrobicularia plana, sex ratio, English Channel 
1. Introduction

Intersex

In gonochoristic (dioecious) organisms, intersex is defined as the abnormal condition of being intermediate between male and female sexes, a hermaphrodite. In recent decades the phenomenon of intersex has been used as a biological indicator of the impact of endocrine disrupting chemicals (EDC) in aquatic environments. The occurrence of oocytes within testicular tissue (ovotestis) of male gonochorists is one example of the intersex condition and has been reported across several classes of aquatic vertebrates (notably fish and amphibians) and also within several invertebrate phyla, where functional hermaphrodites are not known to occur, or are extremely rare. Other biological endpoints for EDCs have also been employed, including induction of the egg yolk precursor vitellogenin in male individuals, or genital malformations (notably imposex in female dogwhelks). Arguably however, it is the simple endpoints, such as ovotestis or imposex, which are the most valuable and cost-effective to apply within large-scale assessments over a broad geographical area.

The estuarine clam Scrobicularia plana (Da Costa 1778) is a common euryhaline intertidal species that is widely distributed in estuarine muddy sediments from the Norwegian and Baltic Seas south to Senegal (Santos et al., 2011, Tebble, 1976). It is predominantly a deposit-feeder, but may also feed on suspended material (Hughes, 1969, Kennedy, 1993) and forms an important component of the diets of estuarine birds and fish (Hughes, 1970, Martins et al., 2013, Moreira, 1994, Moreira, 1995, Wanink \& Zwarts, 1996, Wouters \& Cabral, 2009). Since estuarine sediments act to sequester and concentrate aquatic contaminants, and act as longer-term reservoirs of pollutants, deposit-feeding organisms such as Scrobicularia plana are also useful biomonitors to assess estuarine pollution and biological effects (Boldina-Cosqueric et al., 2010, Bryan \& Hummerstone, 1978, Bryan \& Langston, 1992, Chesman \& Langston, 2006, Langston \& Burt, 1991, Langston et al., 2007, Ruiz et al., 1997). Scrobicularia plana is considered to be gonochoristic (Hughes, 1971, Rodriguez-Rua et al., 2003, Sola, 1997) although it exhibits latitudinal variations in its reproductive patterns: In northern areas there is one reproductive period per year, peaking in June/July (Chesman \& Langston, 2006, Hughes, 1971, Lebour, 1938, Raleigh \& Keegan, 2006, Warwick \& Price, 1975). Further south, this reproductive period may be prolonged with spawning occurring between April and July in the Bay of Arcachon (Bachelet, 1982) and March to September in SW Spain, incorporating two peak periods in May and July (Rodriguez-Rua et al., 2003). Similar characteristic patterns have been noted in other 
marine molluscs and related to north-south temperature gradients and likely success in settlement and survival of offspring (Bowman \& Lewis, 1986, Kendall \& Lewis, 1986, Lewis, 1986, Orton, 1920). Intersex in Scrobicularia plana was first reported in a population from the Avon Estuary, South Devon, UK (Chesman \& Langston, 2006) where the intersex condition was described as feminization of male individuals and a scoring index was presented to categorize the severity of the intersex condition from the occurrence of single oocytes in otherwise normal testicular tissue, through to largely mature ovarian tissue containing small amounts of abnormal testicular tissue. Subsequently, intersex has also been reported in Scrobicularia plana from Mweeloon Bay, Galway (Raleigh \& Keegan, 2006); the Guadiana Estuary, Portugal (Gomes et al., 2009); and 13 estuaries in NW France (Tankoua et al., 2012).

Intersex has also been reported in other gonochoristic bivalve species: Low levels of hermaphroditism (ovotestis) have been recorded in the mussel Perumytilus purpuratus from Argentina (Montenegro Villalobos et al., 2010) and in the razor clam Tagelus plebius and Giant Coquina Iphigena brasiliana from Brazil (Ceuta et al., 2007). Low incidences of ovotestis (<1.5\%) were also reported in two species of Anadara (Bivalvia: Arcidae) from Indonesia, but in these instances, both species were found to be sequential protandric hermaphrodites, changing from males to females as size/age increased (Afiati, 2007). Similarly, two individuals out of a total of 150 Ruditapes decussatus (L.) from the Galician coast (Spain) displayed ovotestis and were suggested to be cases of consecutive hermaphroditism in this species which is considered to be strictly gonochoristic (Delgado \& Camacho, 2002). However, in situ studies of Ruditapes decussatus and Cerastoderma glaucum from areas receiving effluent from waste water treatment plants within the Gulf of Gabès (Tunisia) showed 'many cases of hermaphrodite clams' (Hamza-Chaffai, 2013) although the author does not specify the proportion.

The aim of the current study was to assess the occurrence and extent of intersex (ovotestis) in the estuarine clam Scrobicularia plana within the English Channel and adjacent coastal areas.

\section{Materials and Methods}

In total, over 3000 adult clams were collected from 108 intertidal locations along the English Channel coast and neighbouring areas (Table 1) during the summer periods of 2009 to 2012 . Sampling of $S$. plana for determination of intersex was restricted to this period (approximately late-June to mid- 
August) since this represents the peak of gonad development in the region (Langston et al., 2007). Wherever possible, at least 30 clams were collected by hand, or by digging with a fork, at each of the field locations, using the characteristic star-shaped marks or siphon holes on the sediment surface as a guide to location. Previous studies (Langston et al., 2007) have shown that a sample of 30 individuals is adequate for determination of gender, intersex and M:F sex ratio, yet remains achievable at most sites and avoids unnecessary oversampling. S. plana reaches sexual maturity around 2 to 3 years after settlement, by which time shell lengths are $>20 \mathrm{~mm}$. Ideally, samples comprising individuals of approximately $40 \mathrm{~mm}$ shell length were preferred, although ultimately, size depended on the composition of the local population at each site. All field samples were mixed sex samples since there is no external distinction between the sexes. All clams were retained in a small amount of native sediment in polythene bags and kept cool in insulated containers for transport to the MBA laboratory. Some French samples were sent to MBA in insulated containers via 24 hour courier. Once in the laboratory all clams were rinsed of adhering sediment and placed in tanks of diluted seawater (50:50 mixture of offshore seawater and tap water) for 2 days to enable depuration of ingested particulate material. Once depurated, individual clams were measured (maximum shell length) and weighed (whole including shell) before opening by carefully cutting both adductor muscles, thus exposing the soft tissue and allowing the gonad to be excised. Gonad tissue was carefully removed and placed on a microscope slide under a $22 \times 22 \mathrm{~mm}$ coverslip in a 'squash' preparation for examination under a light microscope to determine gender, development stage, and any anomalies such as intersex and/or parasitism (Chesman \& Langston, 2006). The Chi-squared test was performed on data for gender in order to determine any significant departures from unity in the sex ratio (M:F ratio) of each sample. In preparations where intersex was present, the degree of ovotestis was categorized on a scale 1 to 6 , based on the number and distribution pattern of oocytes (Chesman \& Langston, 2006).

\section{Results}

Table 1 summarises the key features of clam populations at each of the sites sampled. Of these populations, 37 of 71 UK sites (52\%) included intersexed individuals, while 26 of 37 French sites (70\%) were similarly impacted. Overall therefore, $63 / 108(58 \%)$ of populations sampled from the Channel coast and adjacent areas included intersexed individuals (Figure 1). Within these 63 affected 
populations, the severity of intersex in individual clams varied across the entire classification range (stages 1 to 6 , Table 1, Figure 2). From a total of 130 intersexed individuals, 89 were scored at the lowest level of severity (stage 1), 14 at stage 2 and 10 individuals or less in each of the higher stages (Figure 2). The right-hand column of Table 1 indicates the individual scores recorded at each site and shows that samples from some sites included a single intersexed individual, while samples from other sites comprised multiple intersexed individuals at differing stages of severity. To show the overall severity of intersex in affected populations, the scores for affected individuals have been added

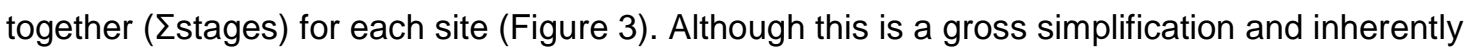
imposes an un-weighted additivity to the $\Sigma$ stages value (i.e. one stage 3 individual is effectively equivalent to three stage 1 individuals) it nevertheless serves to provide an overall summary of severity to complement the summary of incidence (Figure 1). Viewing Figures 1 and 3 together, it is immediately apparent that the intersex condition in S. plana is widespread throughout the Channel region and adjacent areas although severity of impact differs between populations.

Clam populations in some catchments e.g. Camel, Southampton, Pagham, Baie de St Brieuc, Somme, L'Authie and La Canche contained intersexed individuals at all sites sampled (Table 1, Figure 1). Other areas such as the Severn, Tamar/Plym, Yealm, Thames, Baie de Daoulas and Seine sites also contained affected populations (some severely so) yet also contained populations in some areas where no intersexed individuals were found. Despite sampling several populations, no intersexed clams were found in the Fowey, Exe or Axe estuaries; nor in some of the relatively small coastal catchments on the UK south coast and Brittany/Normandy coasts. Notably, at some sites in the Severn (Sand Bay); Tamar (St Germans); Somme (Le Crotoy); L'Authie (Berck) and La Canche (Etaples 2011) clam populations exhibited relatively high incidence of intersex (> 30\% of 'males' affected) generally as a relatively high proportion of low -stage (1 to 2 ) individuals. Some sites (St Brides; Sheppardine; Plym (lower); Le Faou; Plougrescant; Port St Hubert and St Valery sur Mer) in contrast, showed relatively low incidence of intersex (6 to 22\%) but affected individuals included some very high stages (5 and 6 ) representing extensive feminisation of these individuals. There were therefore, no clear correlations between the incidence of intersex (percentage of males affected) and the severity of the condition.

Despite the desire to collect individuals of similar size (approx. $40 \mathrm{~mm}$ ) within all samples, this was not always possible due to the size distribution of the populations at each site. Preliminary analyses of 
individual clam size and weight data revealed that although the data were homoscedastic (Bartlett's test), significant departures from normality were indicated by commonly used tests (Anderson-Darling, Ryan-Joiner and Shapiro-Wilks). However, these normality tests are highly sensitive to even minor departures from normality when sample sizes are large (as is the case here) and should therefore be interpreted with caution and used alongside other assessments of normality (frequency distribution, probability distribution of residuals) when used as justification for using or not using parametric tests (Ahad et al., 2011). Size distributions for male, female and intersex clams are shown in Figure 4 and are clearly very near-normal. Since analysis of variance (ANOVA) is inherently robust to moderate deviations from normality, and since the data were homoscedastic, we therefore feel justified in employing ANOVA to compare the mean sizes of clams sampled across all 108 sites. Results are shown in Table 2 and reveal that there were significant differences in the mean sizes of clams collected at different sites (Figure 5). Data for weights of individual clams showed an almost identical pattern. The size of clams collected from individual sites ranged from a mean of $29.1 \mathrm{~mm}$ (Barry Island, Severn estuary, UK) to $51.7 \mathrm{~mm}$ (Porscav, Ildut estuary, Brittany). There were no obvious patterns in the distribution of mean clam sizes across all sites: some sites were simply characterised by populations of small individuals, other sites by larger individuals. Likely reasons for these differences are uncertain, but probably reflect localised differences in recruitment, growth and mortality. However, when length (or weight) data for all clams from all sites (male, female and intersex) were compared (Figure 4) and tested using ANOVA with sex (male, female or intersex) as a factor (Table 3) it was apparent that there were no significant differences between the mean lengths or weights of male $(38.34 \mathrm{~mm}, 8.37 \mathrm{~g})$ and female $(38.58 \mathrm{~mm}, 8.50 \mathrm{~g})$ clams, but intersexed clams $(37.41 \mathrm{~mm}, 7.33 \mathrm{~g})$ were, on average, slightly smaller than females, but not males (length: $P=0.037$; weight: $P=0.003$ ANOVA). Essentially therefore, there was no overall difference in the mean length, nor weight, of intersexed and normal male clams.

The male:female ratios of samples collected at each site were tested (Chi-squared) to determine whether the ratio showed significant departure from unity. In this context the 'male' proportion included both normal and intersexed males. Taking all sites into consideration the overall mean M:F ratio was 1.007 , indicating approximately equal numbers of males and females in adult populations of S. plana sampled within the Channel region (Figure 6). However, at some sites, significant departures $(P<0.05, n=30$, Chi-squared test) from this 1:1 ratio were observed. Samples from 9 sites were 
significantly biased towards females including: Greenhill, Teign estuary; Calenick Creek and Tresillian, Fal estuary; L’Elorn, Baie de Brest; Milinou, La Penze; St Benoit; St Germaine; Pont de Normandie, Seine estuary and St Valery sur Mer, Somme estuary. In contrast, samples from St Brides, Severn estuary; Saltash, Tamar estuary; Otter estuary; Northam, Southampton water; Porsgwen, Baie de Daoulas and St Jacut, Le Drouet were significantly biased towards males. For the remaining sites, 16 samples showed M:F ratios of 1:1; 48 samples were female biased and 28 were male biased (Figure 6), although these variations were not significant $(P>0.05$ Chi-squared test, $n=30)$.

Parasitism is a factor that has been implicated as a causative agent in the intersexuality of several aquatic organisms. A range of parasites were recorded from the clams collected in this study. Overall, $45 \%$ of all clams examined contained parasites. Most commonly, these comprised small ciliates that were observed rotating within the live gonad tissue preparations. The presence of ciliates was only semi-quantitatively assessed as 'few' or 'many' since our primary focus during examination of live material was the assessment of intersex. Other notable parasites that were recorded included the protist Trichodina sp., and the trematodes Paravortex scrobiculariae, Proctoeces maculatus and Himasthla leptosoma. Data for the frequencies of different parasitic infections in female, male and intersex clams were compared using a Chi-squared contingency table test. The null hypothesis is that there is no association between the frequency of infection by the different categories of parasites and the sex of the clams. Data for trematode infections (including cercariae) were grouped into a single category, since frequencies were otherwise $<5$ for some individual parasites and would prevent testing. The resultant contingency table including observed and expected frequencies is shown in Table 4 and results are summarised in Figure 7. The resultant value of Chi-squared (1115.25) was significantly greater than the critical value $(\mathrm{P}<0.001)$ indicating that there were differences in infestation between female, male and intersexed clams. Female clams were consistently the least parasitized with $<22 \%$ of females containing parasites of any kind. Table 4 shows that observed numbers of non-parasitized females were much higher than expected values, and that infestation with ciliates and Trichodina were lower than expected if no association had occurred. In contrast, male clams were the most commonly parasitized with an infestation rate $>75 \%$, including higher incidence of parasitism by ciliates and Trichodina. Infestation by trematodes and other parasites showed minor contribution to the overall value of Chi-squared, with little difference between observed and expected 
values indicating very limited differences between sexes for these categories. Notably, intersexed 'male' clams were much less frequently infested by parasites $(26 \%)$ than normal males and showed an overall pattern of infestation more similar to that of females (Figure 7).

\section{Discussion}

The present study represents one of the most widespread and extensive investigations of disrupted sexual development in an estuarine bivalve species. Although Scrobicularia plana is considered to be gonochoristic (Hughes, 1971, Rodriguez-Rua et al., 2003, Sola, 1997) evidence from this investigation shows that the intersex condition, in this case manifest as the presence of oocytes in testicular tissue (ovotestis), is widespread throughout the Channel region and adjacent areas. Within this region, clam populations at $58 \%$ of the 108 sites sampled contained intersexed individuals with an overall mean value of $8.6 \%$ of individual male clams exhibiting ovotestis. Although very low incidences of intersex (up to $1.5 \%$ of males affected) have been reported in populations of gonochoristic bivalves (Afiati, 2007, Ceuta et al., 2007, Delgado \& Camacho, 2002, Montenegro Villalobos et al., 2010) the widespread and elevated occurrences of intersex reported here for Scrobicularia plana far exceed these 'occasional' or 'accidental' levels seen in other species. Elevated levels of intersex in Scrobicularia plana have previously been reported from sites within and beyond the present study. At several sites in Southwest UK, between $9 \%$ and $44 \%$ of male clams exhibited ovotestis, rising to $100 \%$ at one site in the Severn estuary (Langston et al., 2007). Investigations at thirteen estuaries in NW France (including 3 sites very close to those in the present study) showed intersex in all populations sampled, with maximum incidences of $>50 \%$ of the male population affected (Tankoua et al., 2012) comparable to the most impacted populations in the present study. Similarly, intersex in male clams from a single site in the Guadiana estuary in Southern Portugal varied between $5.9 \%$ and $71 \%$ during 2007 (Gomes et al., 2009). Clearly, the occurrence of intersexed male Scrobicularia plana is a widespread and consistent feature at many locations within the Channel region.

The present study also showed that the majority of cases of intersex encountered were of low severity: 'focal' (Stage 1); 'diffuse' or 'cluster' (Stages 2 or 3 respectively) using the severity scoring index (Chesman \& Langston, 2006). Higher levels of feminisation were occasionally encountered 
(Stages 4 to 6) but were relatively uncommon. However, there appears to be no simple association between the incidence of intersex (\% of males affected) and the severity of the condition; a feature that has been noted previously (Tankoua et al., 2012). Several estuarine areas were extensively impacted through either high incidence or severity of ovotestis. Sites within the Severn, Camel, Southampton, Pagham, Canche, L'Authie and Somme estuaries, together with the Baie de St Brieuc contained some of the most impacted populations. Nevertheless, the present study also showed that many sites and even entire systems, such as the Fowey, Exe and Axe estuaries in the UK, supported populations of Scrobicularia plana that did not contain intersexed individuals, suggesting that strict gonochorism could still be the true baseline condition for Scrobicularia plana. Equally intriguing is the observation that several estuaries supported affected and unaffected populations of clams in close proximity. An example is the Thames estuary, including the Swale and Medway estuaries in its outer reaches: here, several affected and unaffected sites lie within a few kilometres of each other, with no systematic pattern or gradient of impact. Similarly, whilst clams on the north bank of the Seine at Le Havre and Pont de Normandie contained intersexed males, on the opposite bank at Honfleur there was no evidence of ovotestis. There were similar examples of affected and unaffected populations within several of the smaller estuaries e.g. Fal, Tamar, Yealm and Poole Harbour.

Besides variations in the incidence and severity of intersex, significant shifts in sex ratios were observed in clam populations at some sites. Samples from 9 sites were significantly female-biased, although only 4 of these samples included intersexed individuals. Furthermore, only one of the intersexed samples included severely affected (Stage 5 and 6) individuals, where it may have been possible to assess highly affected males as 'females', thus wrongly skewing the M:F ratio. Therefore it appears unlikely that female-biased populations are the result of erroneous assessment, but neither do they correlate with the incidence of intersex. Two examples of significant female bias in samples of Scrobicularia plana were noted in previous studies (Tankoua et al., 2012) together with one instance of a male-biased sample, a feature that was believed to have previously been unreported. However, our results from the present study also show significantly male-biased samples from 6 locations. Reasons for male-bias are uncertain, since these affected locations were widely dispersed and very different in character from small rural sites to industrialised port areas. However, it is interesting to speculate that some locations with male-biased samples were located within areas known to be affected by TBT contamination (Tamar and Southampton estuaries). 
The overall picture from the present study is therefore one of widespread occurrence of intersexuality in Scrobicularia plana from the Channel region and adjacent areas, although the detailed nature of incidence, severity and sex-ratio perturbations appears complex and irregular. The occurrence of intersex does not appear to be related to the size of adult clams, or to the presence of internal parasitic organisms. Evidence from non-intersexed populations suggests that strict gonochorism is probably the natural condition for Scrobicularia plana and the absence of sex-related differences in the sizes of individuals suggests that protandry or protogyny are not reproductive strategies for this species.

Previous studies have linked intersex in molluscs to a wide range of endocrine disrupting chemicals (EDC) paralleling the well documented occurrence of endocrine disruption, including intersex, in freshwater fish. Several studies have linked the occurrence of intersex, or other measures of endocrine disruption in invertebrates to sewage treatment works (STW) effluents (Andrew-Priestley et al., 2012, Chambers et al., 1997, Gagne et al., 2001, Gross et al., 2001, Jobling et al., 2004, Moore \& Stevenson, 1991, Quinn et al., 2004, Zulkosky et al., 2002), or known areas of anthropogenic contamination (Barbeau \& Grecian, 2003, Gagne et al., 2002, Gauthier-Clerc et al., 2002, Horiguchi et al., 2000, Lee et al., 2010, Lye et al., 2005, Matozzo \& Marin, 2007, Moore \& Stevenson, 1991). Wider field and experimental studies on fish and invertebrates have also shown that intersex can be induced by exposure to endocrine disruptors, including natural and synthetic hormones (Andrew et al., 2010, Langston et al., 2007, Mori et al., 1969); anti-androgens (Alvarez-Munoz et al., this volume, Kang et al., 2006); alkylphenols (Langston et al., 2007, Servos, 1999) and metals (Ali et al., 2010, Ju et al., 2009, Ketata et al., 2007, Pastorinho et al., 2009, Sieratowicz et al., 2011). However, although invertebrates including molluscs may contain and respond to vertebrate-type hormones and their analogues (Croll \& Wang, 2007, Ketata et al., 2008), it has been argued that molluscs do not have the capability to synthesise the complete steroid hormone system as vertebrates and that the evidence for the presence of functional steroid receptors in molluscs is weak such that the detailed mechanisms of EDC action in molluscs remains uncertain (Fernandes et al., 2011, Scott, 2012, Scott, 2013). Recent transcriptomic studies have investigated gene regulation in intersexed and normal clams indicating that transcripts involved with testicular development energy production/transfer, intracellular signalling pathways and egg yolk precursor protein are significantly differentially regulated at selected sites with varying intersex incidence and contaminant burdens (Ciocan et al., this volume). 
The latter study has suggested that sex ratios were correlated with oestrogenic activity, as opposed to anti-androgenic activity, of sediments. However, the mechanistics of EDC impact in molluscs remains an area where more research effort is required.

Besides exposure to STW effluents and generalised estuarine pollution, endocrine disruption in a range of species has been reported to be associated with agriculture (McCoy et al., 2008, Orton \& Routledge, 2011); aquaculture (Ford et al., 2007); pharmaceutical manufacture (Sanchez et al., 2011); paper mill effluent (Pollock et al., 2010) and urbanisation (Schultz et al., 2013, Skelly et al., 2010). Given the very broad range of agricultural activities, industry, urbanisation and population density within the catchments bordering the Channel region; the superimposition of natural variables such as rainfall, run-off, hydrodynamic regimes and sediment dynamics; together with the wide range of potential causative chemicals, it is perhaps not surprising that such complex patterns of intersex in Scrobicularia plana were apparent across the survey area. Further investigations within individual catchments and sub-catchments, together with integrated analysis of chemical and biological data (e.g. intersex) including catchment data (e.g. population, land use, livestock density, STW inputs etc.) may provide further insight into the relative importance of these factors at individual sites. These field investigations should be coupled with targeted experiments investigating the causes and mechanisms of intersex initiation, using different classes of contaminants suspected of involvement in the phenomenon. Once these processes are better understood, then Regulatory Authorities will be able to make better informed decisions over catchment management to protect the downstream aquatic environment.

\section{Acknowledgements}

This work was part funded by the European Regional Development Fund in the framework of the INTERREG IVa France (Channel) England programme (DIESE and Channel Catchments Cluster (3C) projects).

\section{References}

Afiati N. (2007) Hermaphroditism in Anadara granosa (L.) and Anadara antiquata (L.) (BIVALVIA: ARCIDAE) from Central Java. Journal of Coastal Development, 10(3), 171-179. 
Ahad N.A., Yin T.S., Othman A.R. and Yaacob C.R. (2011) Sensitivity of Normality Tests to Nonnormal Data. Sains Malaysiana, 40(6), 637-641.

Ali I., et al. (2010) Estrogen-Like Effects of Cadmium in Vivo Do Not Appear to be Mediated via the Classical Estrogen Receptor Transcriptional Pathway. Environmental Health Perspectives, 118(10), 1389-1394.

Alvarez-Munoz D., et al. (this volume) Widespread contamination of coastal sediments in the Transmanche Channel with anti-androgenic compounds and implications for endocrine disruption of benthic organisms. Marine Pollution Bulletin.

Andrew-Priestley M.N., et al. (2012) Estrogen mediated effects in the Sydney rock oyster, Saccostrea glomerata, following field exposures to sewage effluent containing estrogenic compounds and activity. Aquatic Toxicology, 120, 99-108.

Andrew M.N., O'Connor W.A., Dunstan R.H. and MacFarlane G.R. (2010) Exposure to 17 alphaethynylestradiol causes dose and temporally dependent changes in intersex, females and vitellogenin production in the Sydney rock oyster. Ecotoxicology, 19(8), 1440-1451.

Bachelet G. (1982) Some problems related to secondary production estimates - Example of the Bivalves Macoma balthica and Scrobicularia plana. Oceanologica Acta, 5(4), 421-431.

Barbeau M.A. and Grecian L.A. (2003) Occurrence of intersexuality in the amphipod Corophium volutator (Pallas) in the upper Bay of Fundy, canada. Crustaceana, 76, 665-679.

Boldina-Cosqueric I., et al. (2010) Biochemical, physiological and behavioural markers in the endobenthic bivalve Scrobicularia plana as tools for the assessment of estuarine sediment quality. Ecotoxicology and Environmental Safety, 73(7), 1733-1741.

Bowman R.S. and Lewis J.R. (1986) Geographical variation in the breeding cycles and recruitment of Patella spp. Hydrobiologia, 142, 41-56.

Bryan G.W. and Hummerstone L.G. (1978) Heavy metals in the burrowing bivalve Scrobicularia plana from contaminated and uncontaminated estuaries. Journal of the Marine Biological Association of the United Kingdom, 58(2), 401-419. 
Bryan G.W. and Langston W.J. (1992) Bioavailability, Accumulation and Effects of Heavy-Metals in Sediments With Special Reference to United-Kingdom Estuaries - a Review. Environmental Pollution, 76(2), 89-131.

Ceuta L.O., Boehs G. and Santos J.d.J.B. Registro de hermafroditas em duas especies de bivalves dioicos - Tagelus plebeius (Lightfoot, 1786) e Iphigenia brasiliana (Lamarck, 1818) no estuario do Rio Cachoeira, Ilheus (BA). Proceedings of the Anais do VIII Congresso de Ecologia do Brasil, Caxambu, 23 a 28 de Setembro de 20072007.

Chambers P.A., et al. (1997) Impacts of municipal wastewater effluents on Canadian waters: A review. Water Quality Research Journal of Canada, 32(4), 659-713.

Chesman B.S. and Langston W.J. (2006) Intersex in the clam Scrobicularia plana: a sign of endocrine disruption in estuaries? Biology Letters, 2(3), 420-422.

Ciocan C., et al. (this volume) Intersex related gene expression profiles in clams Scrobicularia plana: molecular markers and environmental deployment. Marine Pollution Bulletin.

Croll R.P. and Wang C. (2007) Possible roles of sex steroids in the control of reproduction in bivalve molluscs. Aquaculture, 272(1-4), 76-86.

Delgado M. and Camacho A.P. (2002) Hermaphroditism in Ruditapes decussatus (L.) (Bivalvia) from the Galician coast (Spain). Scientia Marina, 66(2), 183-185.

Fernandes D., Loi B. and Porte C. (2011) Biosynthesis and metabolism of steroids in molluscs. Journal of Steroid Biochemistry and Molecular Biology, 127(3-5), 189-195.

Ford A.T., Read P.A., Jones T.L., Michino F., Pang Y. and Fernandes T.F. (2007) An investigation into intersex amphipods and a possible association with aquaculture. Marine Environmental Research, 64(4), 443-455.

Gagne F., Blaise C., Pellerin J. and Gauthier-Clerc S. (2002) Alteration of the biochemical properties of female gonads and vitellins in the clam Mya arenaria at contaminated sites in the Saguenay Fjord. Marine Environmental Research, 53(3), 295-310. 
Gagne F., Blaise C., Salazar M., Salazar S. and Hansen P.D. (2001) Evaluation of estrogenic effects of municipal effluents to the freshwater mussel Elliptio complanata. Comparative Biochemistry and Physiology,, 128C(2), 213-225.

Gauthier-Clerc S., Pellerin J., Blaise C. and Gagne F. (2002) Delayed gametogenesis of Mya arenaria in the Saguenay fjord (Canada): a consequence of endocrine disruptors? Comparative Biochemistry and Physiology,, 131C(4), 457-467.

Gomes T., Gonzalez-Rey M. and Bebianno M.J. (2009) Incidence of intersex in male clams Scrobicularia plana in the Guadiana Estuary (Portugal). Ecotoxicology, 18(8), 1104-1109.

Gross M.Y., Maycock D.S., Thorndyke M.C., Morritt D. and Crane M. (2001) Abnormalities in sexual development of the amphipod Gammarus pulex (L.) found below sewage treatment works. Environmental Toxicology and Chemistry, 20(8), 1792-1797.

Hamza-Chaffai A. (2013) Estrogenic Endocrine Disruptors and their Possible Deleterious Effects on Marine Organisms: Use of a Novel Monitoring Bioassay. International Journal of Biotechnology for Wellness Industries, 2, 1-9.

Horiguchi T., et al. (2000) Ovo-testis and disturbed reproductive cycle in the giant abalone, Haliotis madaka: possible linkage with organotin contamination in a site of population decline. Marine Environmental Research, 50(1-5), 223-229.

Hughes R.N. (1969) A Study of Feeding in Scrobicularia plana. Journal of the Marine Biological Association of the United Kingdom, 49(3), 805-823.

Hughes R.N. (1970) Population dynamics of the bivalve Scrobiculara plana (Da Costa) on an intertidal mud-flat in North Wales. Journal of Animal Ecology, 39(2), 333-\&.

Hughes R.N. (1971) Reproduction of Scrobicularia plana Da Costa (Pelecypoda: Semelidae) in North Wales. Veliger., 14(1), 77-81.

Jobling S., et al. (2004) Comparative responses of molluscs and fish to environmental estrogens and an estrogenic effluent: erratum. Aquatic Toxicology, 66(2), 207-222. 
Ju S.M., Park J.J. and Lee J.S. (2009) Induction of Intersex and Masculinization of the Equilateral Venus, Gomphina veneriformis (Bivalvia: Veneridae) by Zinc. Animal Cells and Systems, 13(3), 339344.

Kang I.J., et al. (2006) Anti-androgen flutamide affects gonadal development and reproduction in medaka (Oryzias latipes). Marine Environmental Research, 62, S253-S257.

Kendall M.A. and Lewis J.R. (1986) Temporal and spatial patterns in the recruitment of Gibbula umbilicalis. Hydrobiologia, 142, 15-22.

Kennedy A.D. (1993) Minimal Predation Upon Meiofauna By Endobenthic Macrofauna in the Exe Estuary, South-West England. Marine Biology, 117(2), 311-319.

Ketata I., Denier X., Hamza-Chaffai A. and Minier C. (2008) Endocrine-related reproductive effects in molluscs. Comparative Biochemistry and Physiology C-Toxicology \& Pharmacology, 147(3), 261270.

Ketata I., Smaoui-Damak W., Guermazi F., Rebai T. and Hamza-Chaffai A. (2007) In situ endocrine disrupting effects of cadmium on the reproduction of Ruditapes decussatus. Comparative Biochemistry and Physiology C-Toxicology \& Pharmacology, 146(3), 415-430.

Langston W.J. and Burt G.R. (1991) Bioavailability and effects of sediment-bound TBT in depositfeeding clams, Scrobicularia plana. Marine Environmental Research, 32(1-4), 61-77.

Langston W.J., Burt G.R. and Chesman B.S. (2007) Feminisation of male clams Scrobicularia plana from estuaries in Southwest UK and its induction by endocrine-disrupting chemicals. Marine Ecology-Progress Series, 333, 173-184.

Lebour M.V. (1938) Notes on the breeding of some Lamellibranchs from Plymouth and their larvae. Journal of the Marine Biological Association of the United Kingdom, 23(1), 119-144.

Lee J.S., et al. (2010) Intersexuality of Crassostrea gigas and Ruditapes philippinarum in Southern Coastal Waters of Korea. Environmental Health \& Toxicology, 25(4), 287-294.

Lewis J.R. (1986) Latitudinal trends in reproduction, recruitment and population characteristics of some rocky littoral mollusks and cirripedes. Hydrobiologia, 142, 1-13. 
Lye C.M., Bentley M.G., Clare A.S. and Sefton E.M. (2005) Endocrine disruption in the shore crab Carcinus maenas - a biomarker for benthic marine invertebrates? Marine Ecology Progress Series, 288, 221-232.

Martins R.C., Catry T., Santos C.D., Palmeirim J.M. and Granadeiro J.P. (2013) Seasonal Variations in the Diet and Foraging Behaviour of Dunlins Calidris alpina in a South European Estuary: Improved Feeding Conditions for Northward Migrants. PloS one, 8(12).

Matozzo V. and Marin M.G. (2007) First evidence of altered vitellogenin-like protein levels in clam Tapes philippinarum and in cockle Cerastoderma glaucum from the Lagoon of Venice. Marine Pollution Bulletin, 55(10-12), 494-504.

McCoy K.A., Bortnick L.J., Campbell C.M., Hamlin H.J., Guillette L.J., Jr. and St. Mary C.M. (2008) Agriculture Alters Gonadal Form and Function in the Toad Bufo marinus. Environmental Health Perspectives, 116(11), 1526-1532.

Montenegro Villalobos D., Olivares Paz A. and Teresa Gonzalez M. (2010) Hermaphroditism in Marine Mussel Perumytilus purpuratus (Lamarck, 1819), (Mollusca: Mytilidae). International Journal of Morphology, 28(2), 569-573.

Moore C.G. and Stevenson J.M. (1991) The occurrence of intersexuality in harpacticoid copepods and its relationship with pollution. Marine Pollution Bulletin, 22(2), 72-74.

Moreira F. (1994) Diet, prey-size selection and intake rates of Black-Tailed Godwits Limosa limosa feeding on mudflats. Ibis, 136(3), 349-355.

Moreira F. (1995) Diet of Black-headed Gulls Larus ridibundus on emerged intertidal areas in the Tagus estuary (Portugal): Predation or grazing? Journal of Avian Biology, 26(4), 277-282.

Mori K., Muramatsu T. and Nakamura Y. (1969) Effect of steroid: III. Sex reversal from male to female in Crassostrea gigas by estradiol-17h. Bulletin of the Japanese Society of Scientific Fisheries, 35, 1072-1076. 
Orton F. and Routledge E. (2011) Agricultural intensity in ovo affects growth, metamorphic development and sexual differentiation in the Common toad (Bufo bufo). Ecotoxicology, 20(4), 901911.

Orton J.H. (1920) Sea-Temperature, Breeding and Distribution in Marine Animals. Journal of the Marine Biological Association of the United Kingdom (New Series), 12(2), 339-366.

Pastorinho M.R., Telfer T.C. and Soares A.M.V.M. (2009) Amphipod intersex, metals and latitude: A perspective. Marine Pollution Bulletin, 58(6), 812-817.

Pollock M.S., Dube M.G. and Schryer R. (2010) Investigating the link between pulp mill effluent and endocrine disruption: Attempts to explain the presence of intersex fish in the Wabigoon River, Ontario, Canada. Environmental Toxicology and Chemistry, 29(4), 952-965.

Quinn B., Gagne F., Costello M., McKenzie C., Wilson J. and Mothersill C. (2004) The endocrine disrupting effect of municipal effluent on the zebra mussel (Dreissena polymorpha). Aquatic toxicology (Amsterdam, Netherlands), 66(3), 279-292.

Raleigh J. and Keegan B.F. (2006) The gametogenic cycle of Scrobicularia plana (Mollusca : Bivalvia) in Mweeloon Bay (Galway, west coast of Ireland). Journal of the Marine Biological Association of the United Kingdom, 86(5), 1157-1162.

Rodriguez-Rua A., Prado M.A., Romero Z. and Bruzon M. (2003) The gametogenic cycle of Scrobicularia plana (da Costa, 1778) (Mollusc : Bivalve) in Guadalquivir estuary (Cadiz, SW Spain). Aquaculture, 217(1-4), 157-166.

Ruiz J.M., Szpunar J. and Donard O.F.X. (1997) Butyltins in sediments and deposit-feeding bivalves Scrobicularia plana from Arcachon Bay, France. Science of the Total Environment, 198(3), 225-231. Sanchez W., et al. (2011) Adverse effects in wild fish living downstream from pharmaceutical manufacture discharges. Environment International, 37(8), 1342-1348.

Santos S., Luttikhuizen P.C., Campos J., Heip C.H.R. and van der Veer H.W. (2011) Spatial distribution patterns of the peppery furrow shell Scrobicularia plana (da Costa, 1778) along the European coast: A review. Journal of Sea Research, 66(3), 238-247. 
Schultz M.M., Minarik T.A., Martinovic-Weigelt D., Curran E.M., Bartell S.E. and Schoenfuss H.L. (2013) Environmental estrogens in an urban aquatic ecosystem: II. Biological effects. Environment International, 61, 138-149.

Scott A.P. (2012) Do mollusks use vertebrate sex steroids as reproductive hormones? Part I: Critical

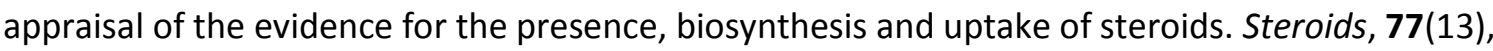
$1450-1468$.

Scott A.P. (2013) Do mollusks use vertebrate sex steroids as reproductive hormones? II. Critical review of the evidence that steroids have biological effects. Steroids, 78(2), 268-281.

Servos M.R. (1999) Review of the aquatic toxicity, estrogenic responses and bioaccumulation of alkylphenols and alkylphenol polyethoxylates. Water Quality Research Journal of Canada, 34(1), 123177.

Sieratowicz A., Stange D., Schulte-OehImann U. and Oehlmann J. (2011) Reproductive toxicity of bisphenol $\mathrm{A}$ and cadmium in Potamopyrgus antipodarum and modulation of bisphenol A effects by different test temperature. Environmental Pollution, 159(10), 2766-2774.

Skelly D.K., Bolden S.R. and Dion K.B. (2010) Intersex Frogs Concentrated in Suburban and Urban Landscapes. Ecohealth, 7(3), 374-379.

Sola J.C. (1997) Reproduction, population dynamics, growth and production of Scrobicularia plana da Costa (pelecypoda) in the Bidasoa estuary, Spain. Netherlands Journal of Aquatic Ecology, 30, 283-296.

Tankoua O.F., Amiard-Triquet C., Denis F., Minier C., Mouneyrac C. and Berthet B. (2012) Physiological status and intersex in the endobenthic bivalve Scrobicularia plana from thirteen estuaries in northwest France. Environmental Pollution, 167, 70-77.

Tebble N. (1976) British Bivalve Seashells, Edinburgh: H.M.S.O.

Wanink J.H. and Zwarts L. (1996) Can food specialization by individual Oystercatchers Haematopus ostralegus be explained by differences in prey specific handling efficiencies? Ardea, 84A(SISI), 177198. 
Warwick R.M. and Price R. (1975) Macrofaunal production in an estuarine mud-flat. Journal of the Marine Biological Association of the United Kingdom, 55(1), 1-18.

Wouters N. and Cabral H.N. (2009) Are flatfish nursery grounds richer in benthic prey? Estuarine Coastal and Shelf Science, 83(4), 613-620.

Zulkosky A.M., Ferguson P.L. and McElroy A.E. (2002) Effects of sewage-impacted sediment on reproduction in the benthic crustacean Leptocheirus plumulosus. Marine Environmental Research, 54(3-5), 615-619. 
Table 1. Sampling locations for Scrobicularia plana from the English Channel coast and adjacent area (includes numbers of male, female,

intersexed and undifferentiated clams together with degree of severity (IS stage) according to the assessment scale (Chesman \& Langston, 2006).

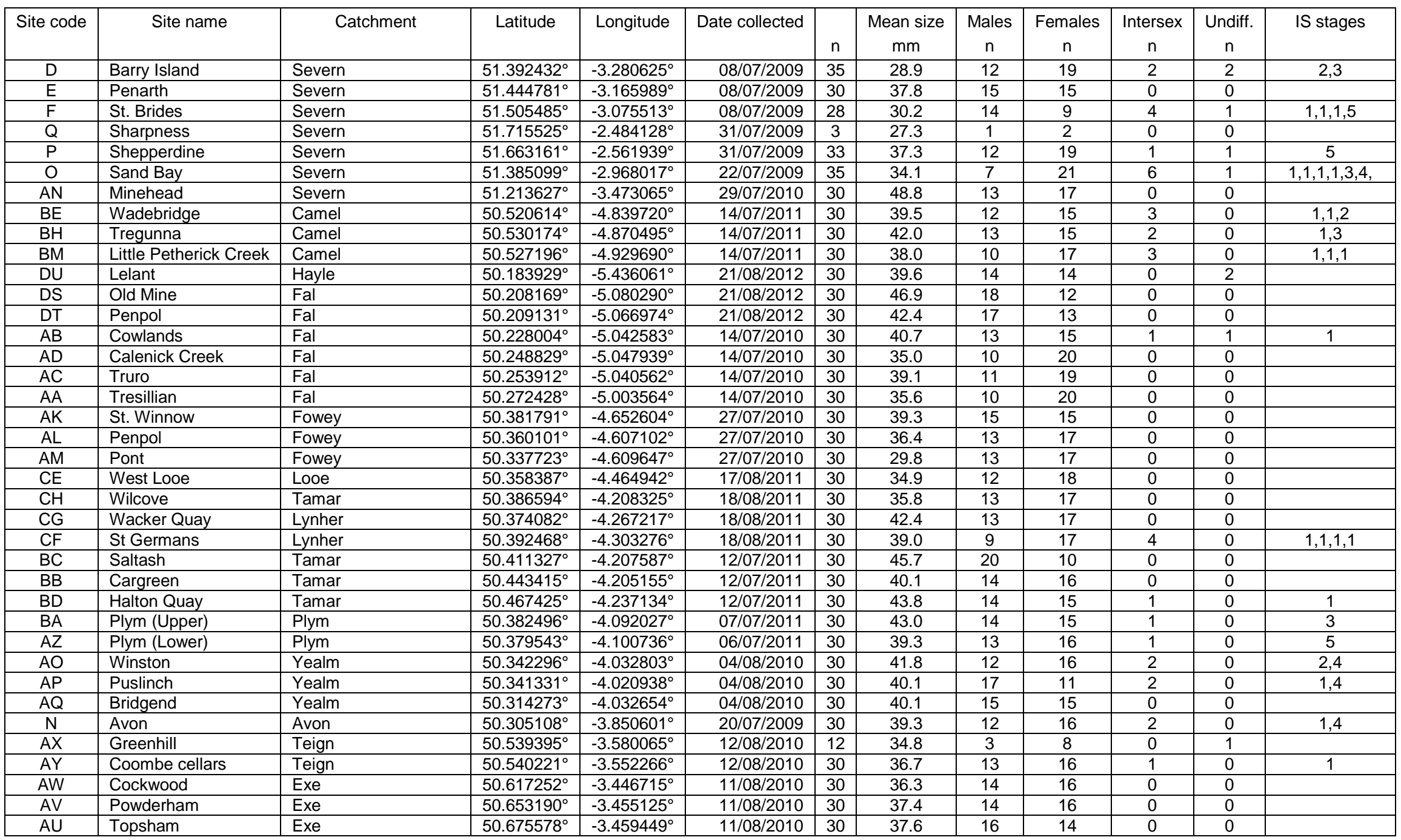




\begin{tabular}{|c|c|c|c|c|c|c|c|c|c|c|c|c|}
\hline AT & Otter & Otter & $50.631631^{\circ}$ & $-3.311073^{\circ}$ & $09 / 08 / 2010$ & 30 & 33.5 & 21 & 8 & 1 & 0 & 2 \\
\hline AR & Axe Mid & Axe & $50.713976^{\circ}$ & $-3.056104^{\circ}$ & 09/08/2010 & 30 & 36.3 & 17 & 13 & 0 & 0 & \\
\hline AS & Axe Lower & Axe & $50.706643^{\circ}$ & $-3.058520^{\circ}$ & 09/08/2010 & 30 & 41.0 & 16 & 14 & 0 & 0 & \\
\hline $\mathrm{C}$ & Wytch Farm & Poole & $50.671672^{\circ}$ & $-2.034340^{\circ}$ & $03 / 07 / 2009$ & 36 & 40.9 & 11 & 17 & 2 & 6 & 3,4 \\
\hline$A$ & Lytchett & Poole & $50.722284^{\circ}$ & $-2.036097^{\circ}$ & $30 / 06 / 2009$ & 30 & 39.6 & 15 & 15 & 0 & 0 & \\
\hline $\mathrm{B}$ & Parkstone & Poole & $50.713996^{\circ}$ & $-1.956909^{\circ}$ & $30 / 06 / 2009$ & 28 & 40.2 & 14 & 14 & 0 & 0 & \\
\hline $\mathrm{L}$ & Totton & Southampton & $50.919059^{\circ}$ & $-1.477949^{\circ}$ & $16 / 07 / 2009$ & 30 & 31.0 & 13 & 14 & 3 & 0 & $1,2,3$ \\
\hline $\mathrm{M}$ & Cracknore & Southampton & $50.897037^{\circ}$ & $-1.427678^{\circ}$ & 16/07/2009 & 30 & 36.2 & 15 & 10 & 3 & 2 & $1,1,2$ \\
\hline 1 & Woolston & Southampton & $50.889721^{\circ}$ & $-1.383937^{\circ}$ & $15 / 07 / 2009$ & 30 & 36.3 & 11 & 16 & 2 & 1 & 1,1 \\
\hline $\mathrm{J}$ & Northam & Southampton & $50.916337^{\circ}$ & $-1.377505^{\circ}$ & $15 / 07 / 2009$ & 30 & 32.1 & 18 & 9 & 1 & 2 & 1 \\
\hline $\mathrm{K}$ & St Denys & Southampton & $50.921581^{\circ}$ & $-1.381278^{\circ}$ & $15 / 07 / 2009$ & 30 & 33.4 & 16 & 11 & 3 & 0 & $1,1,1$ \\
\hline $\mathrm{G}$ & Warsash & Southampton & $50.855764^{\circ}$ & $-1.308027^{\circ}$ & $14 / 07 / 2009$ & 30 & 34.0 & 14 & 13 & 3 & 0 & $1,1,1$ \\
\hline $\mathrm{H}$ & Mid-Hamble & Southampton & $50.872236^{\circ}$ & $-1.305442^{\circ}$ & $14 / 07 / 2009$ & 30 & 39.6 & 13 & 15 & 2 & 0 & 1,1 \\
\hline$T$ & Pagham West & S. coast & $50.760325^{\circ}$ & $-0.784419^{\circ}$ & $06 / 07 / 2010$ & 30 & 46.1 & 11 & 17 & 2 & 0 & 3,3 \\
\hline$S$ & Pagham East & S. coast & $50.771494^{\circ}$ & $-0.756551^{\circ}$ & $06 / 07 / 2010$ & 30 & 42.6 & 12 & 16 & 2 & 0 & 1,2 \\
\hline $\mathrm{R}$ & Littlehampton & S. coast & $50.815256^{\circ}$ & $-0.560517^{\circ}$ & $06 / 07 / 2010$ & 44 & 40.5 & 23 & 20 & 1 & 0 & 1 \\
\hline $\mathrm{U}$ & Shoreham Lower & S. coast & $50.830394^{\circ}$ & $-0.273099^{\circ}$ & $07 / 07 / 2010$ & 30 & 39.1 & 16 & 13 & 1 & 0 & 1 \\
\hline V & Shoreham Upper & S. coast & $50.837720^{\circ}$ & $-0.285260^{\circ}$ & $07 / 07 / 2010$ & 30 & 37.7 & 19 & 11 & 0 & 0 & \\
\hline $\mathrm{Y}$ & Newhaven & S. coast & $50.795377^{\circ}$ & $0.050938^{\circ}$ & $07 / 07 / 2010$ & 5 & 31.8 & 2 & 3 & 0 & 0 & \\
\hline W & Rye Lower & S. coast & $50.941933^{\circ}$ & $0.758119^{\circ}$ & $08 / 07 / 2010$ & 30 & 40.9 & 15 & 14 & 1 & 0 & 2 \\
\hline $\mathrm{X}$ & Ramsgate & S. coast & $51.319224^{\circ}$ & $1.363113^{\circ}$ & $08 / 07 / 2010$ & 30 & 40.8 & 14 & 15 & 1 & 0 & 1 \\
\hline $\mathrm{AE}$ & Ferry Inn & Thames & $51.354846^{\circ}$ & $0.891718^{\circ}$ & $19 / 07 / 2010$ & 30 & 35.0 & 13 & 17 & 0 & 0 & \\
\hline $\mathrm{AG}$ & Swale Causeway & Thames & $51.362276^{\circ}$ & $0.777829^{\circ}$ & $19 / 07 / 2010$ & 30 & 35.8 & 14 & 16 & 0 & 0 & \\
\hline $\mathrm{AF}$ & Queenborough & Thames & $51.416877^{\circ}$ & $0.739786^{\circ}$ & $19 / 07 / 2010$ & 30 & 35.3 & 12 & 17 & 1 & 0 & 1 \\
\hline $\mathrm{AH}$ & Funton Creek & Thames & $51.383706^{\circ}$ & $0.708273^{\circ}$ & $20 / 07 / 2010$ & 30 & 33.0 & 13 & 16 & 1 & 0 & 2 \\
\hline $\mathrm{Al}$ & Strand & Thames & $51.390567^{\circ}$ & $0.582556^{\circ}$ & $20 / 07 / 2010$ & 30 & 38.5 & 15 & 15 & 0 & 0 & \\
\hline $\mathrm{BP}$ & Tilbury & Thames & $51.452065^{\circ}$ & $0.369681^{\circ}$ & $25 / 07 / 2011$ & 30 & 29.0 & 15 & 12 & 1 & 2 & 1 \\
\hline $\mathrm{BN}$ & Coalhouse Fort & Thames & $51.459973^{\circ}$ & $0.431601^{\circ}$ & $26 / 07 / 2011$ & 30 & 36.0 & 15 & 15 & 0 & 0 & \\
\hline $\mathrm{BL}$ & Mucking & Thames & $51.504012^{\circ}$ & $0.454955^{\circ}$ & $26 / 07 / 2011$ & 31 & 32.2 & 17 & 12 & 1 & 1 & 5 \\
\hline $\mathrm{BQ}$ & Hole Haven & Thames & $51.510133^{\circ}$ & $0.554677^{\circ}$ & $26 / 07 / 2011$ & 30 & 38.0 & 16 & 13 & 1 & 0 & 1 \\
\hline BS & Canvey Island & Thames & $51.516623^{\circ}$ & $0.625309^{\circ}$ & $26 / 07 / 2011$ & 28 & 35.7 & 12 & 13 & 0 & 3 & \\
\hline BT & Westcliff & Thames & $51.535181^{\circ}$ & $0.685706^{\circ}$ & $26 / 07 / 2011$ & 30 & 36.7 & 9 & 19 & 2 & 0 & 1,1 \\
\hline $\mathrm{BG}$ & Porsgwen & Baie de Daoulas & $48.336104^{\circ}$ & $-4.310231^{\circ}$ & $18 / 07 / 2011$ & 30 & 37.2 & 18 & 10 & 2 & 0 & 1,3 \\
\hline $\mathrm{DB}$ & Le Faou & Baie de Daoulas & $48.295942^{\circ}$ & $-4.181820^{\circ}$ & $20 / 07 / 2012$ & 30 & 36.8 & 16 & 11 & 3 & 0 & $5,5,5$ \\
\hline DF & Daoulas & Baie de Daoulas & $48.356000^{\circ}$ & $-4.266500^{\circ}$ & $20 / 07 / 2012$ & 30 & 35.0 & 16 & 14 & 0 & 0 & \\
\hline $\mathrm{CQ}$ & L'Elorn & Baie de Brest & $48.408146^{\circ}$ & $-4.351349^{\circ}$ & $20 / 07 / 2012$ & 30 & 41.9 & 8 & 20 & 2 & 0 & 1,2 \\
\hline $\mathrm{DC}$ & Le Conquet & La Ria & $48.360250^{\circ}$ & $-4.751267^{\circ}$ & $20 / 07 / 2012$ & 30 & 46.8 & 13 & 17 & 0 & 0 & \\
\hline $\mathrm{DI}$ & Porscav & Aber Ildut & $48.460767^{\circ}$ & $-4.758517^{\circ}$ & $21 / 07 / 2012$ & 30 & 44.3 & 12 & 18 & 0 & 0 & \\
\hline $\mathrm{DN}$ & Treglonou & Aber Benoit & $48.552183^{\circ}$ & $-4.534400^{\circ}$ & $21 / 07 / 2012$ & 10 & 47.6 & 3 & 6 & 1 & 0 & 1 \\
\hline $\mathrm{DD}$ & Goulven & La Fleche & $48.636541^{\circ}$ & $-4.295205^{\circ}$ & $21 / 07 / 2012$ & 30 & 51.7 & 12 & 18 & 0 & 0 & \\
\hline $\mathrm{DA}$ & Milinou & La Penze & $48.627177^{\circ}$ & $-3.954947^{\circ}$ & $22 / 07 / 2012$ & 30 & 42.9 & 9 & 21 & 0 & 0 & \\
\hline DJ & Kernou & Riviere du Morlaix & $48.624500^{\circ}$ & $-3.856117^{\circ}$ & $21 / 07 / 2012$ & 30 & 41.8 & 13 & 14 & 0 & 3 & \\
\hline $\mathrm{DE}$ & Plougrescant & Baie d'Enfer & $48.833981^{\circ}$ & $-3.219010^{\circ}$ & $22 / 07 / 2012$ & 30 & 44.3 & 15 & 14 & 1 & 0 & 5 \\
\hline DK & Lancerf & Le Trieux & $48.761950^{\circ}$ & $-3.119700^{\circ}$ & $23 / 07 / 2012$ & 30 & 43.9 & 11 & 16 & 3 & 0 & $1,3,5$ \\
\hline CS & Port du Legue & Baie de St. Brieuc & $48.531839^{\circ}$ & $-2.716370^{\circ}$ & $24 / 07 / 2012$ & 30 & 37.5 & 10 & 19 & 1 & 0 & 1 \\
\hline $\mathrm{BF}$ & Hotellerie 2011 & Baie de St. Brieuc & $48.513846^{\circ}$ & $-2.675836^{\circ}$ & $19 / 07 / 2011$ & 30 & 34.4 & 16 & 12 & 2 & 0 & 1,1 \\
\hline
\end{tabular}




\begin{tabular}{|c|c|c|c|c|c|c|c|c|c|c|c|c|}
\hline $\mathrm{DL}$ & Hotellerie 2012 & Baie de St. Brieuc & $48.513846^{\circ}$ & $-2.675836^{\circ}$ & $23 / 07 / 2012$ & 30 & 34.9 & 14 & 15 & 1 & 0 & 1 \\
\hline DM & St Maurice & Le Gouessant & $48.526326^{\circ}$ & $-2.630968^{\circ}$ & $22 / 07 / 2012$ & 30 & 36.7 & 14 & 14 & 2 & 0 & 1,1 \\
\hline $\mathrm{BU}$ & St Jacut 2011 & Le Drouet & $48.593044^{\circ}$ & $-2.183336^{\circ}$ & $19 / 07 / 2011$ & 31 & 37.0 & 16 & 12 & 2 & 1 & 1,1 \\
\hline $\mathrm{CZ}$ & St Jacut 2012 & Le Drouet & $48.590688^{\circ}$ & $-2.183704^{\circ}$ & $21 / 07 / 2012$ & 30 & 35.7 & 21 & 9 & 0 & 0 & \\
\hline $\mathrm{DH}$ & Port St Hubert & La Rance & $48.536102^{\circ}$ & $-1.965609^{\circ}$ & $21 / 07 / 2012$ & 30 & 37.8 & 10 & 18 & 2 & 0 & 1,6 \\
\hline $\mathrm{CP}$ & Rotheneuf & Havre de Rotheneuf & $48.684330^{\circ}$ & $-1.947129^{\circ}$ & $15 / 07 / 2012$ & 30 & 35.0 & 12 & 17 & 1 & 0 & 1 \\
\hline BV & St Benoit 2011 & St Benoit & $48.617510^{\circ}$ & $-1.846788^{\circ}$ & 19/07/2011 & 30 & 36.5 & 7 & 22 & 1 & 0 & 1 \\
\hline CY & St Benoit 2012 & St Benoit & $48.620314^{\circ}$ & $-1.847677^{\circ}$ & $15 / 07 / 2012$ & 29 & 36.5 & 11 & 17 & 1 & 0 & 1 \\
\hline $\mathrm{CX}$ & Regneville 2012 & La Sienne & $49.021323^{\circ}$ & $-1.554823^{\circ}$ & $14 / 07 / 2012$ & 30 & 39.6 & 10 & 19 & 1 & 0 & 1 \\
\hline $\mathrm{CO}$ & St Germaine & Havre de St Germaine & $49.216252^{\circ}$ & $-1.623917^{\circ}$ & $14 / 07 / 2012$ & 30 & 41.2 & 6 & 24 & 0 & 0 & \\
\hline CV & Baie des Veys 2012 & Baie des Veys & $49.356991^{\circ}$ & $-1.185086^{\circ}$ & $11 / 07 / 2012$ & 30 & 49.4 & 16 & 14 & 0 & 0 & \\
\hline CT & Honfleur & Seine & $49.423652^{\circ}$ & $0.207541^{\circ}$ & $20 / 07 / 2012$ & 30 & 38.4 & 11 & 19 & 0 & 0 & \\
\hline DG & Le Havre Port & Seine & $49.449769^{\circ}$ & $0.184708^{\circ}$ & $21 / 07 / 2012$ & 30 & 38.8 & 14 & 15 & 1 & 0 & 1 \\
\hline $\mathrm{CR}$ & Pont de Normandie & Seine & $49.442459^{\circ}$ & $0.271568^{\circ}$ & $20 / 07 / 2012$ & 30 & 36.6 & 7 & 22 & 1 & 0 & 1 \\
\hline $\mathrm{BI}$ & Cap Hornu & Somme & $50.195045^{\circ}$ & $1.502091^{\circ}$ & $26 / 07 / 2011$ & 30 & 36.4 & 10 & 18 & 2 & 0 & 1,1 \\
\hline CK & St Valery sur Mer & Somme & $50.190927^{\circ}$ & $1.623423^{\circ}$ & $08 / 07 / 2012$ & 30 & 42.4 & 8 & 20 & 2 & 0 & 5,6 \\
\hline CJ & Le Crotoy & Somme & $50.217722^{\circ}$ & $1.631298^{\circ}$ & $08 / 07 / 2012$ & 30 & 35.8 & 7 & 19 & 4 & 0 & $1,1,1,2$ \\
\hline $\mathrm{CM}$ & Fort Mahon & L'Authie & $50.362957^{\circ}$ & $1.574736^{\circ}$ & $08 / 07 / 2012$ & 30 & 41.7 & 12 & 16 & 2 & 0 & 1,1 \\
\hline BJ & Berck (1) & L'Authie & $50.369433^{\circ}$ & $1.608333^{\circ}$ & $26 / 07 / 2011$ & 30 & 40.2 & 7 & 15 & 8 & 0 & $1,1,1,1,1,1,2,2$ \\
\hline BW & Berck (2) & L'Authie & $50.371055^{\circ}$ & $1.604660^{\circ}$ & 09/08/2011 & 30 & 39.9 & 11 & 19 & 0 & 0 & \\
\hline $\mathrm{CN}$ & Grofliers & L'Authie & $50.374878^{\circ}$ & $1.596386^{\circ}$ & $08 / 07 / 2012$ & 30 & 42.4 & 15 & 9 & 1 & 5 & 1 \\
\hline $\mathrm{CL}$ & Le Touquet & La Canche & $50.535049^{\circ}$ & $1.598146^{\circ}$ & $09 / 07 / 2012$ & 30 & 38.2 & 14 & 13 & 3 & 0 & $1,1,1$ \\
\hline BK & Etaples 2011 & La Canche & $50.533333^{\circ}$ & $1.608333^{\circ}$ & $26 / 07 / 2011$ & 31 & 34.0 & 9 & 13 & 8 & 1 & $1,1,1,1,1,1,1,2$ \\
\hline CU & Etaples 2012 & La Canche & $50.519976^{\circ}$ & $1.625247^{\circ}$ & 09/07/2012 & 30 & 32.0 & 12 & 16 & 1 & 1 & 1 \\
\hline
\end{tabular}


Table 2. One-way ANOVA: Shell length $(\mathrm{mm})$ versus sample site

\begin{tabular}{|l|c|c|c|c|c|}
\hline Source & DF & SS & MS & F & P \\
\hline Site & 105 & 56044.3 & 533.8 & 52.88 & 0.000 \\
\hline Error & 3013 & 30414.0 & 10.1 & & \\
\hline Total & 3118 & 86458.2 & & & \\
\hline & & & & & \\
\hline $\mathrm{S}=3.177$ & $\mathrm{R}^{2}=64.82 \%$ & $\mathrm{R}^{2}($ adj. $)=63.6 \%$ & & & \\
\hline
\end{tabular}

Table 3. One-way ANOVA: Shell length versus Sex (Male, Female, Intersex)

\begin{tabular}{|l|c|c|c|c|c|}
\hline Source & DF & SS & MS & F & P \\
\hline Sex & 2 & 184.2 & 92.1 & 3.30 & 0.037 \\
\hline Error & 3127 & 87139.9 & 27.9 & & \\
\hline Total & 3129 & 87324.1 & & & \\
\hline & & & & & \\
\hline $\mathrm{S}=5.279$ & $\mathrm{R}^{2}=0.21 \%$ & $\mathrm{R}^{2}$ (adj. $)=0.15 \%$ & & & \\
\hline & & & & & \\
\hline & $\mathbf{n}$ & Mean & Std. Dev. & & \\
\hline Male & 1379 & $38.34 \mathrm{~mm}$ & $5.23 \mathrm{~mm}$ & & \\
\hline Female & 1621 & $38.58 \mathrm{~mm}$ & $5.33 \mathrm{~mm}$ & & \\
\hline Intersex & 130 & $37.41 \mathrm{~mm}$ & $5.09 \mathrm{~mm}$ & & \\
\hline
\end{tabular}

One-way ANOVA: Weight (including shell) versus Sex (Male, Female, Intersex)

\begin{tabular}{|l|c|c|c|c|c|}
\hline Source & DF & SS & MS & F & P \\
\hline Sex & 2 & 164.8 & 82.4 & 5.72 & 0.003 \\
\hline Error & 3127 & 45065.0 & 14.4 & & \\
\hline Total & 3129 & 45229.8 & & & \\
\hline & & & & & \\
\hline $\mathrm{S}=3.796$ & $\mathrm{R}^{2}=0.36 \%$ & $\mathrm{R}^{2}$ (adj.) $=0.30 \%$ & & & \\
\hline & & & & & \\
\hline & $\mathbf{n}$ & Mean & Std. Dev. & & \\
\hline Male & 1379 & $8.37 \mathrm{~g}$ & $3.72 \mathrm{~g}$ & & \\
\hline Female & 1621 & $8.50 \mathrm{~g}$ & $3.91 \mathrm{~g}$ & & \\
\hline Intersex & 130 & $7.33 \mathrm{~g}$ & $2.98 \mathrm{~g}$ & & \\
\hline
\end{tabular}


Table 4. Chi-squared Contingency table for parasitism in Female, Male and Intersex

Scrobicularia plana.

\begin{tabular}{|c|c|c|c|c|c|}
\hline & & Female & Male & Intersex & Total \\
\hline \multirow[t]{3}{*}{ Non-parasitized } & Observed & 1274 & 340 & 96 & 1710 \\
\hline & Expected & 836.67 & 805.46 & 67.9 & \\
\hline & Chi-sq & 228.59 & 268.98 & 11.66 & \\
\hline \multirow[t]{3}{*}{ Few ciliates } & Observed & 205 & 733 & 17 & 955 \\
\hline & Expected & 467.26 & 449.83 & 37.90 & \\
\hline & Chi-sq & 147.20 & 178.25 & 11.53 & \\
\hline \multirow[t]{3}{*}{ Many ciliates } & Observed & 13 & 184 & 10 & 207 \\
\hline & Expected & 101.28 & 97.50 & 8.22 & \\
\hline & Chi-sq & 76.95 & 76.73 & 0.39 & \\
\hline \multirow[t]{3}{*}{ Trichodina } & Observed & 59 & 230 & 6 & 295 \\
\hline & Expected & 144.34 & 138.95 & 11.71 & \\
\hline & Chi-sq & 50.46 & 59.65 & 2.78 & \\
\hline \multirow[t]{3}{*}{ Trematodes (inc. cercariae) } & Observed & 107 & 110 & 5 & 222 \\
\hline & Expected & 108.62 & 104.57 & 8.81 & \\
\hline & Chi-sq & 0.024 & 0.282 & 1.648 & \\
\hline \multirow[t]{7}{*}{ Other parasites } & Observed & 31 & 29 & 3 & 63 \\
\hline & Expected & 30.82 & 29.67 & 2.5 & \\
\hline & Chi-sq & 0.001 & 0.015 & 0.100 & \\
\hline & Total & 1689 & 1626 & 137 & 3452 \\
\hline & Chi-sq & 1115.25 & & & \\
\hline & DF & 10 & & & \\
\hline & P-value & 0.000 & & & \\
\hline
\end{tabular}


Figure Headings

Figure 1. Incidence of intersex in Scrobicularia plana from the English Channel region. Grey circles indicate affected sites and are proportional to the percentage of the male population displaying intersex. Clear circles indicate unaffected sites (details in Table 1).

Figure 2. Severity of intersex in affected Scrobicularia plana using classification scale (Chesman \& Langston, 2006)

Figure 3. Cumulative severity (Estage) of intersex in Scrobicularia plana from the English Channel region. Grey circles indicate affected sites and are proportional to the sum of classification stages (Chesman \& Langston, 2006) at that site. Clear circles indicate unaffected sites (details in Table 1).

Figure 4. Size of male, female and intersexed Scrobicularia plana sampled in this study. Upper figure shows size (maximum shell length) distributions. Lower figure shows mean values (error bars indicate $95 \%$ confidence intervals)

Figure 5. Mean shell length of Scrobicularia plana at each sampling location (means and 95\% confidence intervals shown, ranked by mean values). Diamond symbol indicates intersexed populations. Site codes indicated in Table 1.

Figure 6. Sex ratios (M:F ratio) of Scrobicularia plana at each sampling location. Sites are ranked by $M: F$ ratio and sites showing significant departure from 1:1 ratio (male or female biased) are indicated. Diamond symbol indicates intersexed populations. Site codes indicated in Table 1.

Figure 7. Mean percentages of different parasites observed in male, female and intersexed Scrobicularia plana. 

Figure 1

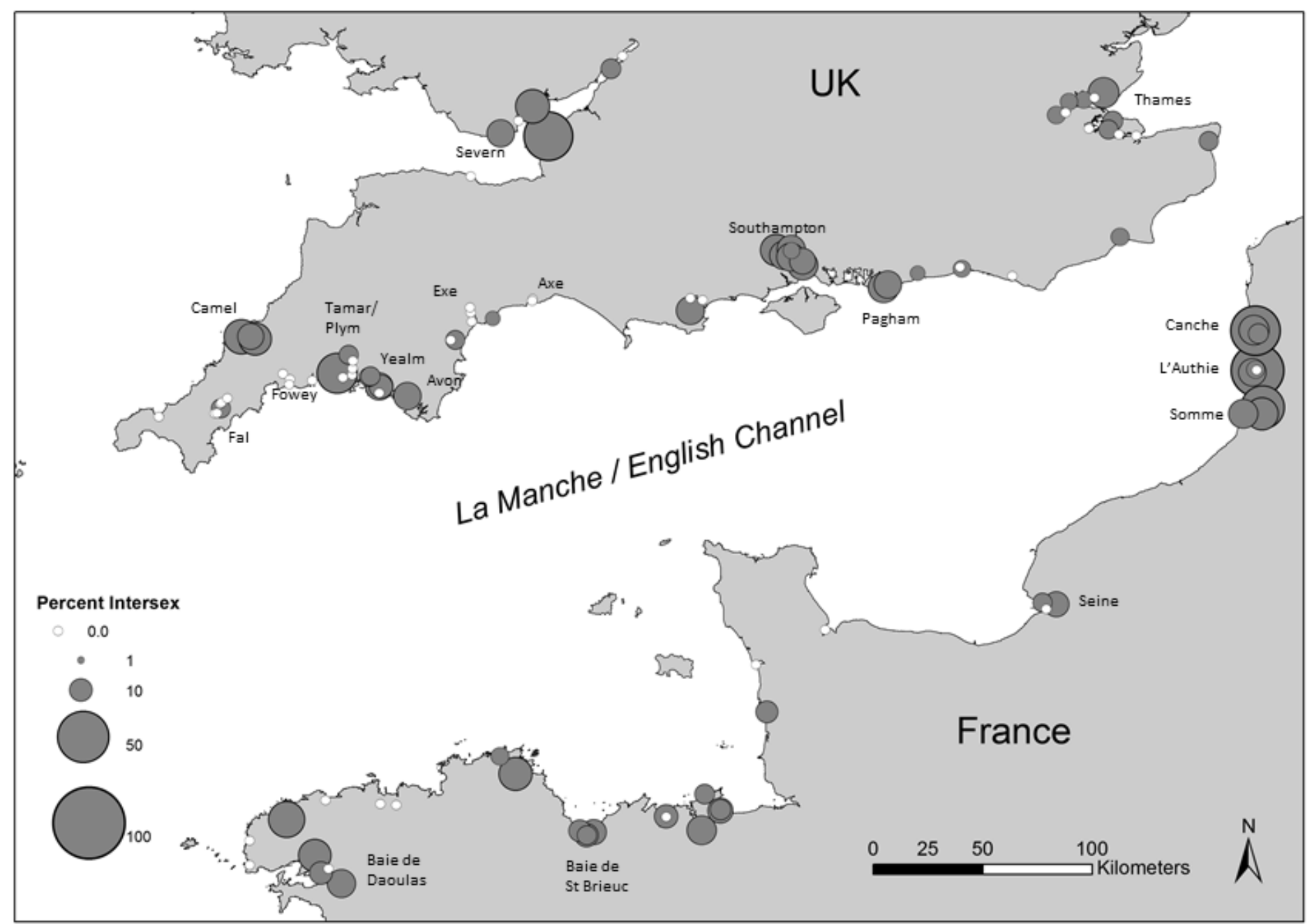


Figure 2

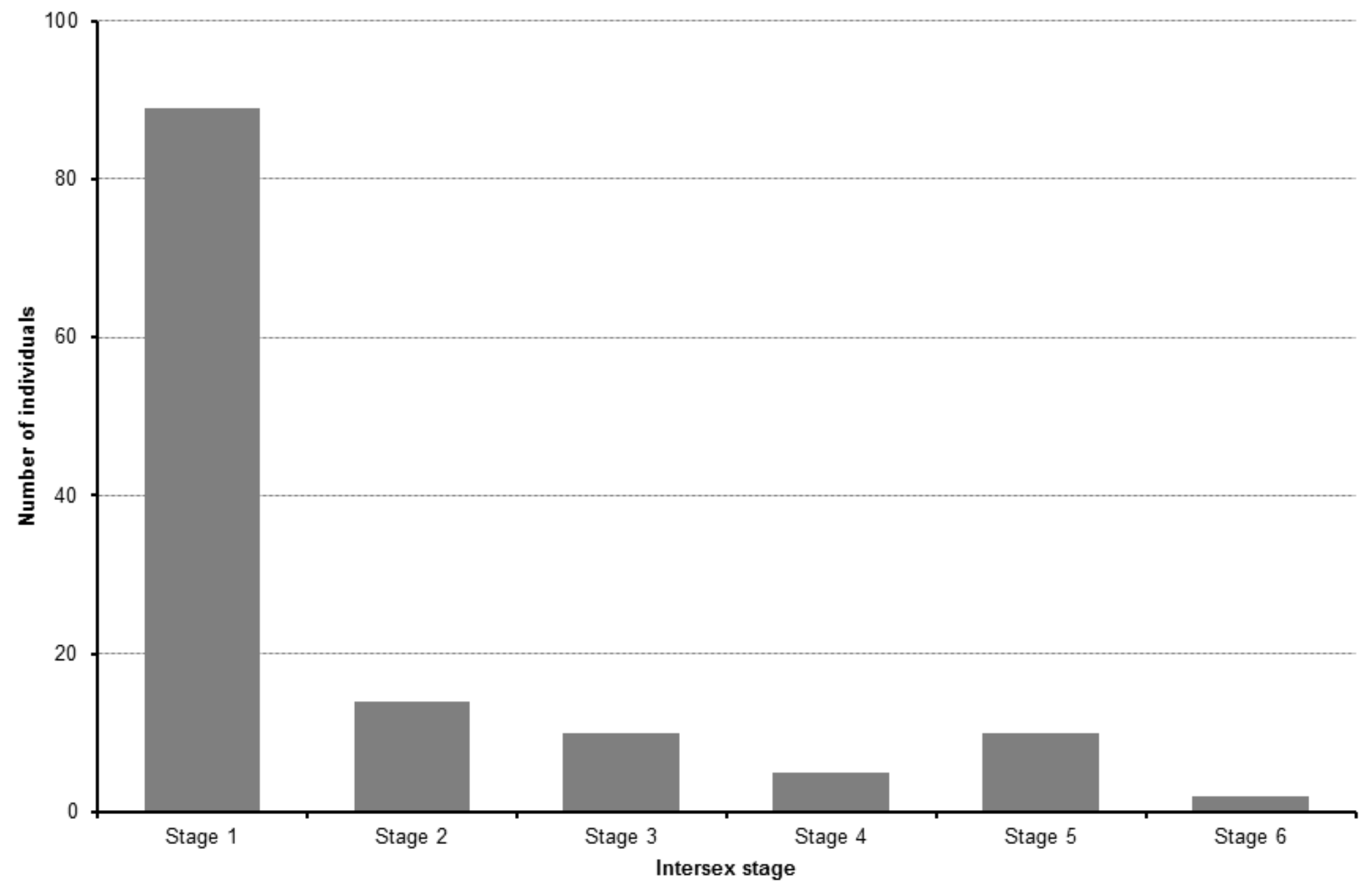


Figure 3

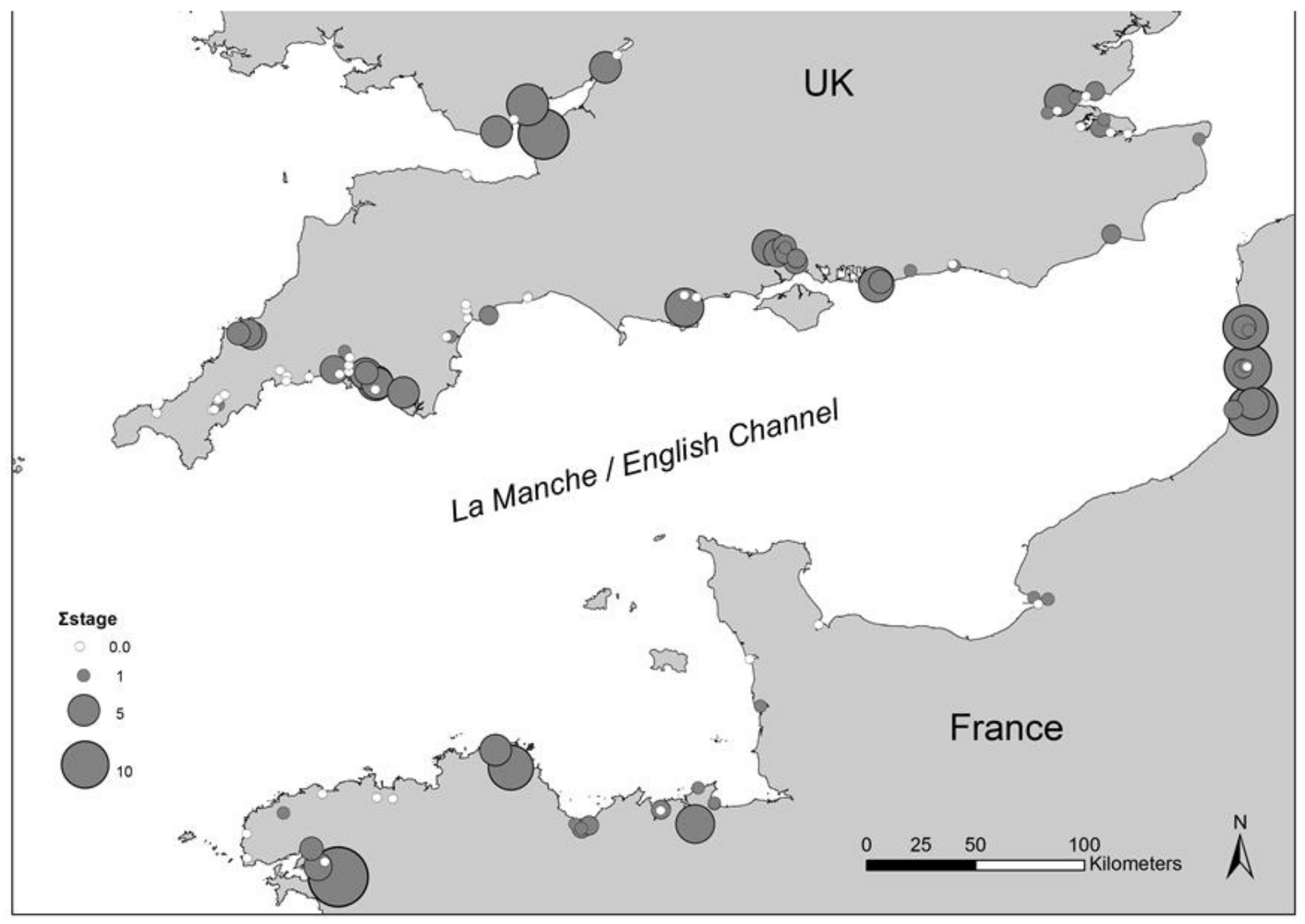


Figure 4
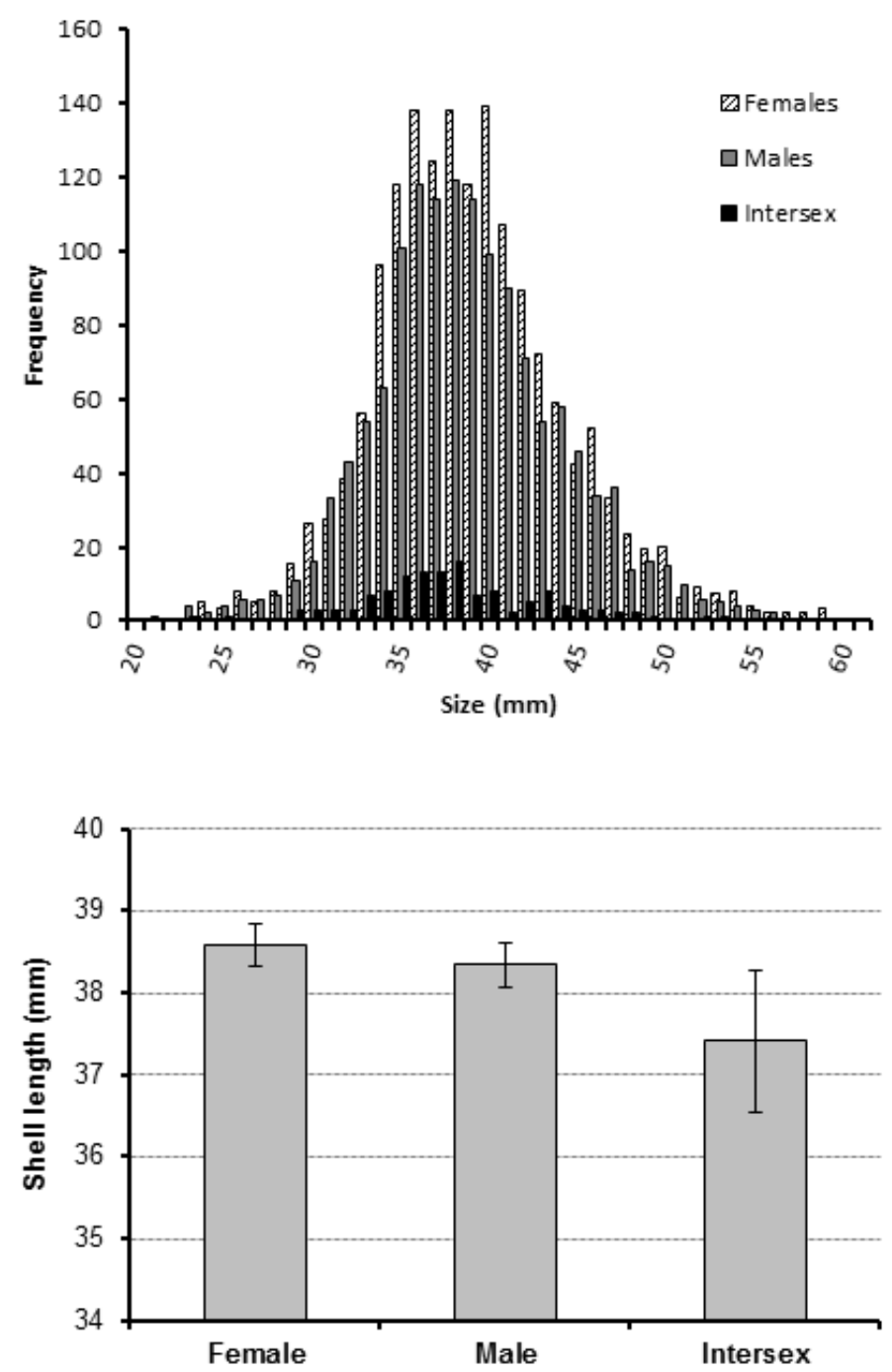
Figure 5

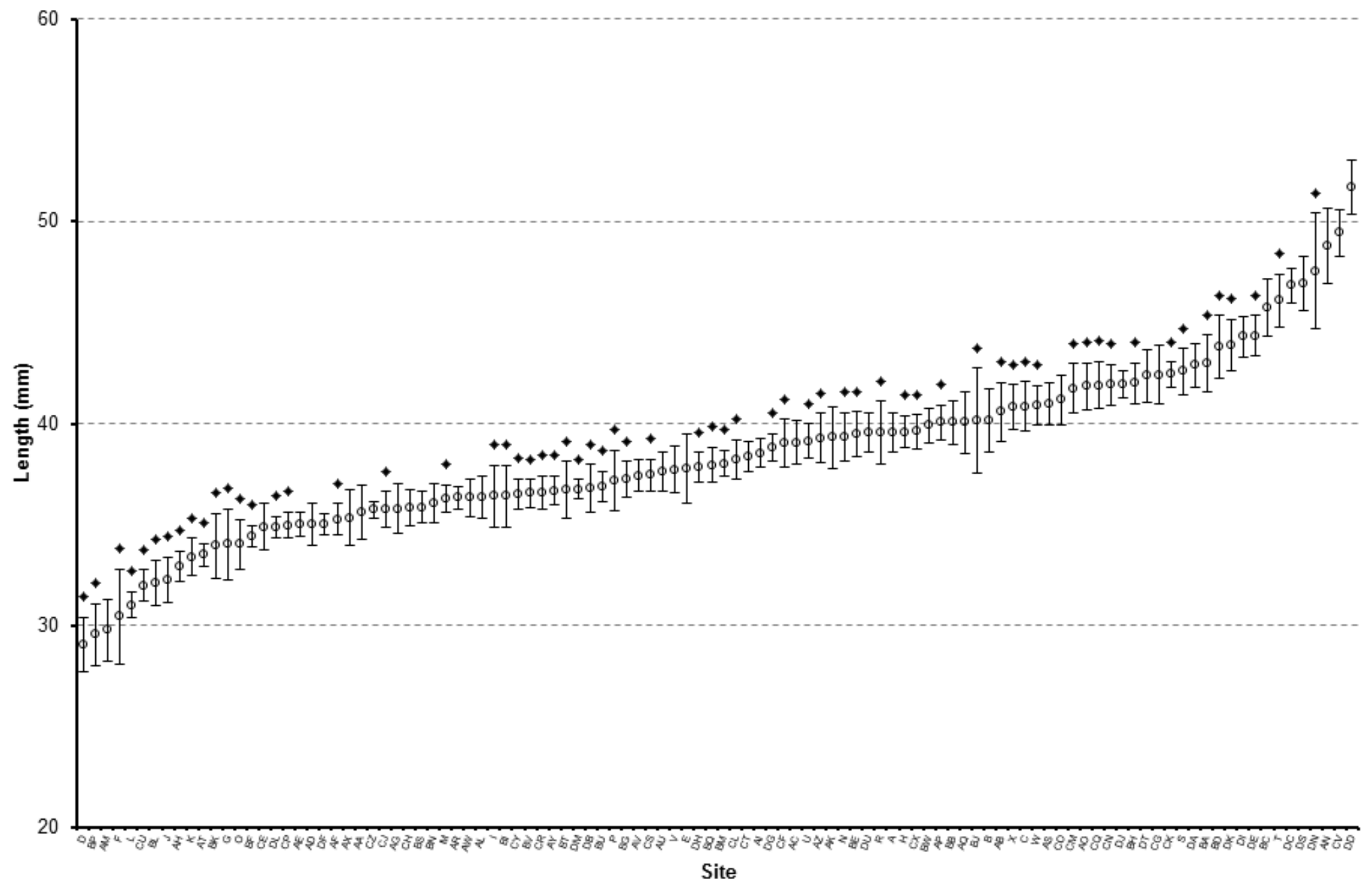


Figure 6

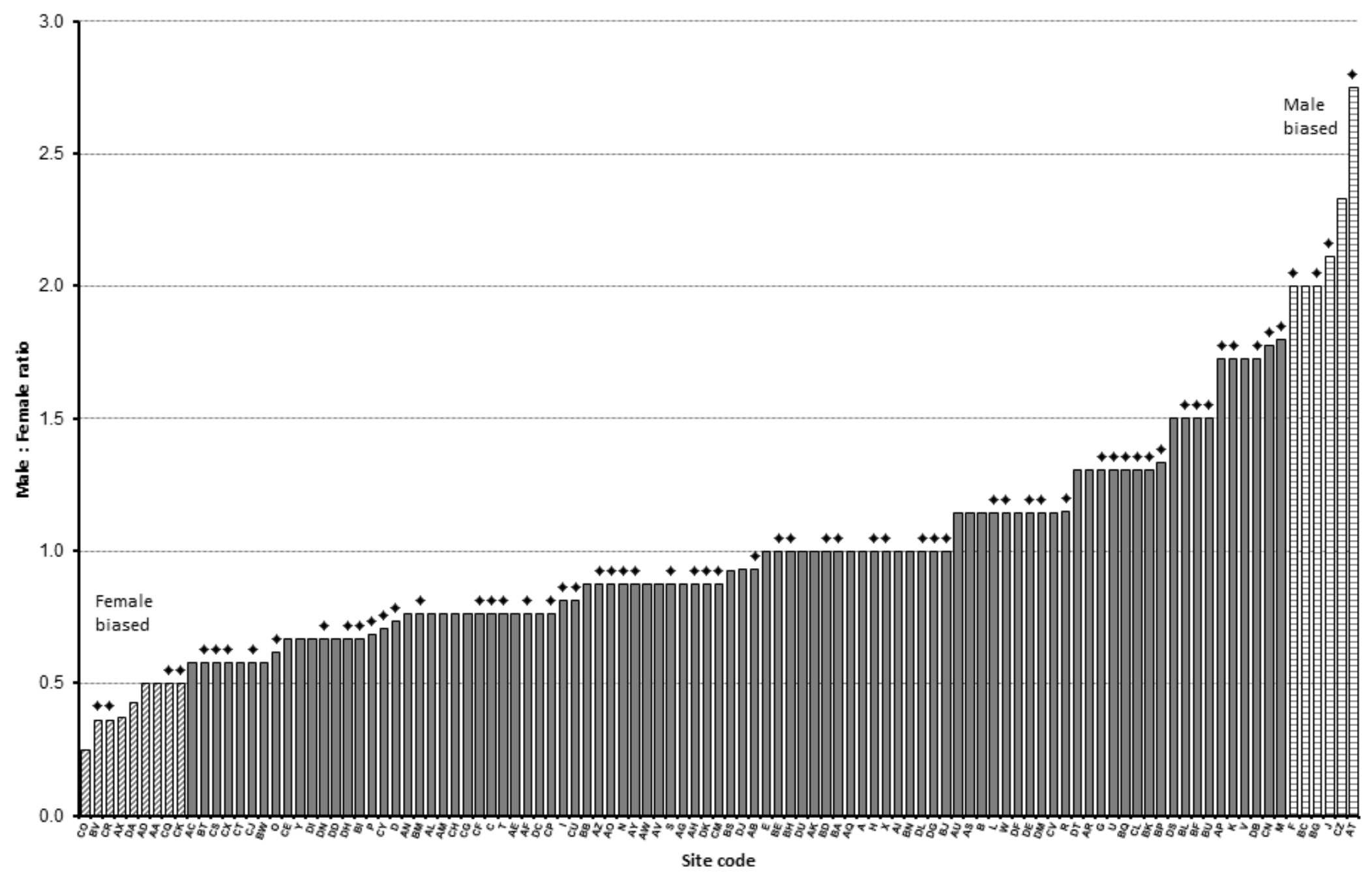




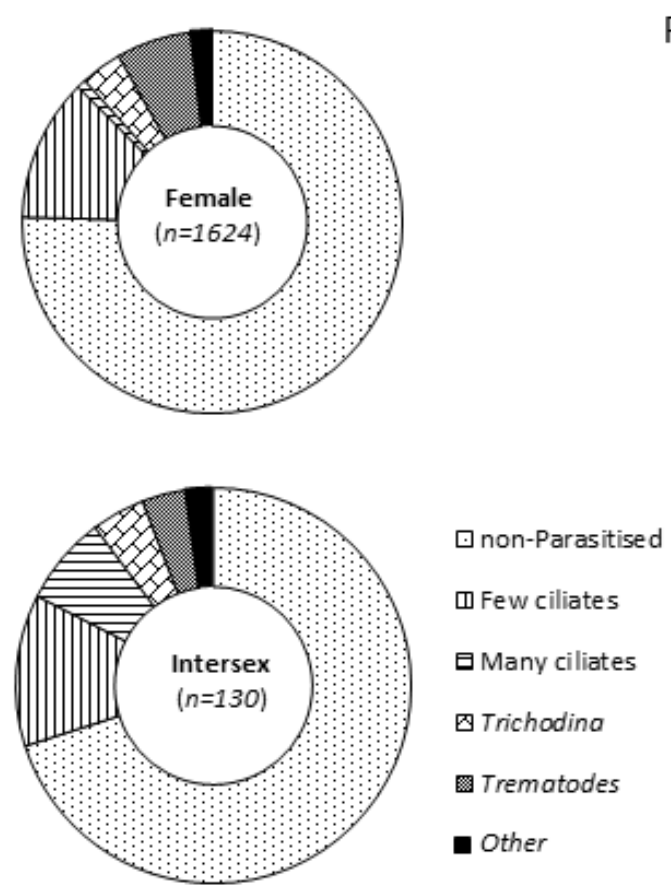

Figure 7

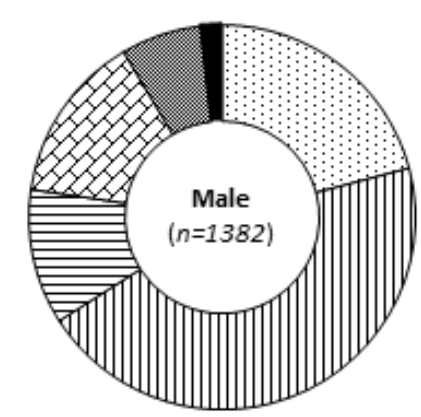

